(C) 2017, THE AUTHORS. Published by FASS and Elsevier Inc. on behalf of the American Dairy Science Association ${ }^{\circledR}$.

This is an open access article under the CC BY-NC-ND license (http://creativecommons.org/licenses/by-nc-nd/3.0/).

\title{
Farm business and operator variables associated with bulk tank somatic cell count from dairy herds in the southeastern United States
}

\author{
Karen L. DeLong, ${ }^{* 1}$ Dayton M. Lambert, ${ }^{*}$ Susan Schexnayder,† Peter Krawczel,‡ Mark Fly,§ \\ Lorraine Garkovich,\# and Steve Oliverł \\ *Department of Agricultural and Resource Economics, \\ †Human Dimensions Research Lab, Department of Forestry, Wildlife and Fisheries, \\ $\ddagger$ Department of Animal Science, and \\ §Department of Forestry, Wildlife and Fisheries, University of Tennessee, Knoxville 37996 \\ \#Community and Leadership Development, University of Kentucky, Lexington 40546-0215
}

\begin{abstract}
Mastitis is a worldwide problem in dairy cows and results in reduced milk production, the culling of cows, and other economic losses. Bulk tank somatic cell count (BTSCC) over 200,000 cells/mL often indicates underlying subclinical mastitis in dairy herds. Several preventative measures that can be implemented to help improve the incidence of mastitis exist, but surveys find these practices not fully adopted by producers. The goal of this research was to analyze the farm and operator characteristics associated with BTSCC in dairy herds by analyzing a survey of dairy producers in the southeastern United States. We examined this region because it has experienced a decline in the number of dairy farms, dairy cows, and milk production over the past 2 decades. The southeast region is also associated with higher BTSCC levels than the national average. Dairy farms in Georgia, Mississippi, Kentucky, North Carolina, South Carolina, Tennessee, and Virginia were surveyed. Producers were asked questions about the BTSCC at which they take action to address BTSCC, the information sources they use to learn about and manage BTSCC, farm structure and management characteristics, and attitudinal variables associated with profitability, managerial control, and planning horizon. Least squares regression was used to determine how these factors were associated with BTSCC levels across the 7-state region. Concern over mastitis, financial consequences of mastitis, and increased previous-year BTSCC were associated with higher current BTSCC levels. Obtaining information about mastitis from veterinarians and extension personnel, taking action against mastitis at a BTSCC less than 300,000 cells/ $\mathrm{mL}$, and perceived ability to control processes and mastitis incidence were associated with reduced BTSCC.
\end{abstract}

Received February 20, 2017.

Accepted July 8, 2017.

${ }^{1}$ Corresponding author: klewis39@utk.edu
We found average BTSCC was lower in North Carolina and Virginia. These results suggest that proactive producers (i.e., those that perceive they can control BTSCC and seek information from reliable sources), were more likely to report lower BTSCC. As a result, it may be possible to achieve improved milk quality, evident from lowered BTSCC, across the region.

Key words: attitudes, concern, mastitis, milk

\section{INTRODUCTION}

Bovine mastitis is an inflammation of the mammary gland most commonly caused by a bacterial infection. Mastitis is one of the most common diseases affecting dairy cattle (Pighetti and Elliott, 2011). Clinical mastitis cases generally reduce milk production and exhibit the typical signs of infection, including swelling, redness, heat, and pain upon touch (National Mastitis Council, 1999). Detection of subclinical mastitis infections rely on measuring the SCC of milk, an indicator of milk quality (Oliver et al., 2004). Although other measures of milk quality, such as standard plate count, provide valuable information, dairy farm operators receive bulk tank SCC (BTSCC) reports with each milk shipment, resulting in a high awareness of this aspect of milk quality. The SCC indicates the degree of immune cell influx in the mammary gland (Pighetti and Elliott, 2011). A milk SCC concentration exceeding 200,000 cells $/ \mathrm{mL}$ generally indicates cows have an underlying intramammary infection, whereas milk with a SCC of less than 200,000 cells/mL indicates that cows are adequately managing pathogen exposure, and SCC less than 100,000 cells/mL generally indicates mammary glands free of infection (Pighetti and Elliott, 2011).

Mastitis is a worldwide problem in dairy cows. Damage costs to the US dairy industry exceed $\$ 1$ billion annually (Ott, 1999; Jones and Bailey, 2009). Although the exact economic cost of mastitis varies across studies, Liang et al. (2017) recently estimated the average cost of mastitis to be in the range of $\$ 326$ per case for pri- 
miparous cows and $\$ 427$ per case for multiparous cows. The costs associated with mastitis include reduced milk production, discarded milk, higher veterinarian costs, higher labor costs, and the culling of cows (Hogeveen and Osteras, 2005; Jones and Bailey, 2009; Cha et al., 2011; Liang et al., 2017).

To prevent economic losses, dairy operators can implement numerous management practices during lactation to treat and reduce mastitis prevalence in their herds. Typical practices include early dry off of affected udder quarters, treating clinical and subclinical mastitis, culling cows with clinical or subclinical mastitis, and maintaining barn and milking hygiene (Hogeveen and Osteras, 2005); however, the adoption of prevention practices may be selective and limited (Olde Riekerink et al., 2005). Mastitis reduction results in increased net returns to farmers (Allore and Erb, 1998; Yalcin et al., 1999; Jones and Bailey, 2009; Cha et al., 2011); accordingly, monetary incentives play a role in the adoption of best practices to manage SCC. However, nonpecuniary factors, including taking pleasure in ensuring animal health and quality of life, may be equally motivating to reduce mastitis (Valeeva et al., 2007).

A growing body of literature worldwide has examined the association between mastitis management practices and BTSCC (e.g., Yalcin et al., 1999; Norman et al., 2000; Rodrigues and Ruegg, 2005; Valeeva et al., 2007; Wenz et al., 2007; Jansen et al., 2009; Schewe et al., 2015). A survey of Dutch dairy farms reported that farmer attitudes and behavior explained variation in the incidence of mastitis and BTSCC (Jansen et al., 2009). Wenz et al. (2007) used data collected by the US National Animal Health Monitory System Dairy to examine the associations between BTSCC and herd management practices. More recently, Schewe et al. (2015) conducted a survey of dairy farmers in Florida, Michigan, and Pennsylvania to determine farmer beliefs and attitudes that were associated with bulk tank BTSCC.

This research examines how farm structure characteristics, operator characteristics, farm management practices, and information sources affect BTSCC of dairy farms in the southeastern United States. The geographic extent of mastitis, and importantly the practices dairy operators use to keep BTSCC low are generally unknown for this region. From 1995 to 2010, the southeastern United States experienced a $64 \%$ decline in the number of dairy farms, lost $47 \%$ of its dairy cow population, and realized a $37 \%$ decline in milk production (Herndon, 2011). Furthermore, a recent USDA report assessing BTSCC by region using Federal Milk Marketing Orders found southeast BTSCC was 88,000 cells/mL higher than the US average of 230,000 cells/mL (USDA-APHIS, 2013). Using a representative survey of dairy operators across a 7-state region, we regressed BTSCC on factors hypothesized to affect SCC controlling for farm management practices, the information sources producers use to learn about and manage mastitis, producer characteristics, and regional variation. We examined specifically the BTSCC at which producers take action to address BTSCC, the information sources producers use to learn about and manage BTSCC, farm structure and management attributes, operator characteristics, and farmer attitudinal variables associated with profitability, control, and planning horizon.

\section{MATERIALS AND METHODS}

\section{Data}

A mail survey of permitted, grade A dairy farms in Georgia, Mississippi, Kentucky, North Carolina, South Carolina, Tennessee, and Virginia was conducted to determine current monthly BTSCC on dairy farms (Table 1). The survey included questions regarding producer experiences, perceptions, and attitudes toward mastitis and mastitis management. Operators reported the dairy's current monthly average BTSCC, as well as monthly average BTSCC 12 and 36 mo prior. Survey mailings occurred in October and November 2013; 4 attempts at contact were made. The overall response rate was 29\% (579 completed surveys from operating dairies). Surveys were completed by the primary decision maker of the dairy. Poststratification weights were developed to benchmark survey response patterns to regional farm population numbers (Lohr, 2010). Summary statistics and regression analysis were weighted with these weighting factors.

The state average and overall average of the surveyed dairies current monthly BTSCC appear in Table 1. North Carolina dairies reported the lowest monthly average BTSCC at 212,940 cells/mL. Mississippi dairies reported the highest monthly average BTSCC at 383,314 cells $/ \mathrm{mL}$. The regional average BTSCC was 254,479 cells/mL.

\section{Empirical Model}

Profit-maximizing producers manage BTSCC by maintaining herd health and using hygienic milking practices. In the short term, high BTSCC could reduce premiums or cause discounts for poor milk quality. Over the medium term, high BTSCC could indicate mastitis in cows that results in declined herd health, loss of milk production, and other added expenses associated with treating mastitis. Farm solvency could be at risk in the long term with respect to productivity, 
revenue, and reputation. Thus, a decision variable in the objective function of profit-maximizing dairy producers could be to minimize the incidence of BTSCC and, concomitantly, mastitis.

Factors hypothesized to affect BTSCC include managerial ability, farm business structure, personal attributes, and subjective BTSCC thresholds maintained by producers that trigger action to be taken to control BTSCC (Table 2). For producer $i$ and period $t$, we hypothesized BTSCC $\left(b_{s c c}\right)$ is explained as a function $(f)$ of the following factors:

$$
\begin{gathered}
\operatorname{btscc}_{i t}= \\
f\left(\operatorname{btscc}_{i, t-1}, F S C_{i}, O C_{i}, F_{S}, \operatorname{THRESH}_{i}, \operatorname{INFO}_{i}, u_{i}\right),
\end{gathered}
$$

where $F S C$ are variables associated with farm structure characteristics; $O C$ are operator attributes; FSM are farm and herd management practices; THRESH indicates a BTSCC reading that elicits producers to take action with respect to treating mastitis; INFO identifies information sources used to diagnose, treat, and manage mastitis; and $u_{i}$ is a random disturbance term beyond the operator's control. A dairy farm's average monthly BTSCC 1 yr ago $\left(b t s c c_{t-1}\right)$ is hypothesized to positively correlate with current monthly average BTSCC (Table 2). For example, dairy farms reporting high (low) BTSCC 1 yr ago may be more (less) likely to report high (low) BTSCC levels. The lagged BTSCC variable also conveys information regarding a producer's ability to manage and react to BTSCC.

Farm structure and operator characteristics are considered fixed because these variables are difficult to change in the medium or long term. Variables included in FSM, THRESH, and INFO are control variables, because they can be adjusted in the short or medium term to address high BTSCC or update herd health management plans. Discussion of the variables included in these components follows.

Farm Structure Characteristics. We hypothesized that larger farms would report lower BTSCC because of efficiencies generated by scale economies (Kumbhakar et al., 1991), and because previous research in the United States has shown larger herd sizes are associated with lower BTSCC (Norman et al., 2000; Wenz et al., 2007; Jayarao et al., 2004; Ingham et al., 2011). Average milk production per day (milkprod) and the number of cows managed by an operation proxies scale economies and may be associated with lower BTSCC. On average, dairies managed 244 milk cows; average milk production per cow was $26 \mathrm{~kg} / \mathrm{d}$ (Table 2 ). The diversity of the farm operation (ofarm, $1=$ other nondairy farming) may affect BTSCC. The percent of dairies managing farm operations in addition to their dairy was $31 \%$. These operators may not consider their dairy operations to be their primary income generating activity. Research has also shown that off-farm income is negatively correlated with dairy operation efficiency (Kumbhakar et al., 1991). Producers earning income from nonfarm jobs may have less time to spend working on the dairy. Therefore, we hypothesized that as the percentage of a dairy farm's off-farm income source increases (oincome; 1: 0\%, 2: 1-25\%, 3: 26-50\%, 4: $51-75 \%, 5:>75 \%$ ), current BTSCC will be higher. The percent of respondents earning income from their farm operation only was $52 \%$.

Table 1. Grade A permitted dairy survey response pattern and current monthly bulk tank somatic cell count

\begin{tabular}{|c|c|c|c|c|c|}
\hline State & $\begin{array}{l}\text { Survey } \\
\text { response } \\
\text { rate }(\%)\end{array}$ & $n^{1}$ & $\begin{array}{c}\text { BTSCC mean } \\
(\text { SEM })\end{array}$ & $\begin{array}{c}\text { Average } \\
\text { surveyed herd } \\
\text { size (SEM) }\end{array}$ & $\begin{array}{c}\text { Average state } \\
\text { herd size }\end{array}$ \\
\hline North Carolina & 21.5 & 49 & $\begin{array}{c}212,940 \\
(11,465)\end{array}$ & $\begin{array}{l}221.89 \\
(43.75)\end{array}$ & 184 \\
\hline Virginia & 30.5 & 172 & $\begin{array}{r}226,583 \\
(7,617)\end{array}$ & $\begin{array}{l}174.70 \\
(19.35)\end{array}$ & 148 \\
\hline Kentucky & 27.9 & 158 & $\begin{array}{r}249,196 \\
(7,682)\end{array}$ & $\begin{array}{l}88.68 \\
(13.00)\end{array}$ & 88 \\
\hline Georgia & 17.6 & 37 & $\begin{array}{l}256,590 \\
(19,299)\end{array}$ & $\begin{array}{c}1,105.90 \\
(578.89)\end{array}$ & 352 \\
\hline South Carolina & 21.4 & 17 & $\begin{array}{l}271,956 \\
(21,993)\end{array}$ & $\begin{array}{l}335.84 \\
(87.15)\end{array}$ & 200 \\
\hline Tennessee & 24.9 & 85 & $\begin{array}{l}309,087 \\
(13,543)\end{array}$ & $\begin{array}{l}178.27 \\
(27.44)\end{array}$ & 124 \\
\hline Mississippi & 19.2 & 16 & $\begin{array}{l}383,314 \\
(43,727)\end{array}$ & $\begin{array}{l}131.90 \\
(20.78)\end{array}$ & 153 \\
\hline Total & 29.0 & 538 & $\begin{array}{r}254,479 \\
(4,940)\end{array}$ & $\begin{array}{l}234.71 \\
(57.73)\end{array}$ & 204 \\
\hline
\end{tabular}
(BTSCC; cells/mL)

${ }^{1} \mathrm{n}$ is the number of surveyed herds reporting BTSCC.

${ }^{2}$ Source: Progressive Dairyman (2014). 
Table 2. Variable definitions and hypothesized signs

\begin{tabular}{|c|c|c|c|c|c|}
\hline Variable & Definition & Units & $\begin{array}{l}\text { Hypothesized } \\
\text { sign }\end{array}$ & $\begin{array}{l}\operatorname{Mean}^{1} \\
(\mathrm{SEM})\end{array}$ & $\mathrm{n}^{2}$ \\
\hline \multicolumn{6}{|c|}{ Farm structure characteristic } \\
\hline btscc $_{2013}$ & $\mathrm{BTSCC}^{3} 1$ yr ago & cells $/ \mathrm{mL}$ & + & $\begin{array}{l}265,028 \\
(5,141.09)\end{array}$ & 538 \\
\hline milkprod & Average milk production per cow & $\mathrm{kg} / \mathrm{d}$ & - & $\begin{array}{l}25.56 \\
(0.33)\end{array}$ & 536 \\
\hline cows & Number of cows & & - & $\begin{array}{c}243.71 \\
(57.73)\end{array}$ & 561 \\
\hline \multirow[t]{5}{*}{ oincome } & Total income from off farm & $\%$ & + & & 553 \\
\hline & & & & 51.52 & \\
\hline & $\begin{array}{l}1-25 \% \\
26-50 \%\end{array}$ & & & $\begin{array}{r}25.01 \\
8.09\end{array}$ & \\
\hline & $51-75 \%$ & & & 7.54 & \\
\hline & $>75 \%$ & & & 7.84 & \\
\hline penalty & $\begin{array}{l}1 \text { if co-op/processor imposes a penalty for exceeding } \\
\text { BTSCC }\end{array}$ & & - & 75.65 & 521 \\
\hline \multicolumn{6}{|c|}{ Operator characteristic } \\
\hline finance & Financial consequences of mastitis are worrisome ${ }^{4}$ & & - & $\begin{array}{c}4.40 \\
(0.03)\end{array}$ & 556 \\
\hline continue & $\begin{array}{l}\text { Likelihood you or a family member will operate farm } \\
\text { in } 5 \text { years? }\end{array}$ & & - & $\begin{array}{l}3.00 \\
(0.05)\end{array}$ & 555 \\
\hline educ & 1 if college degree & $\%$ & - & 24.94 & 560 \\
\hline exper & Years working on farm divided by age & & - & $\begin{array}{c}0.54 \\
(0.01)\end{array}$ & 532 \\
\hline language & $\begin{array}{l}1 \text { if the employees speak same language as owner/ } \\
\text { farm manager }\end{array}$ & $\%$ & $+/-$ & 71.49 & 524 \\
\hline \multicolumn{6}{|c|}{ Farm management practice } \\
\hline milking & $\begin{array}{l}1 \text { if in the parlor and doing the milking at almost } \\
\text { every milking }\end{array}$ & $\%$ & - & 48.01 & 549 \\
\hline concern & $\begin{array}{l}\text { Factor } 1 \text { of the } 18 \text { Likert-scale questions regarding } \\
\text { farmer perceptions of mastitis }{ }^{4}\end{array}$ & & + & $\begin{array}{c}3.57 \\
(0.04)\end{array}$ & 503 \\
\hline thresh2 & Take action: $\mathrm{SCC}=200,000$ cells $/ \mathrm{mL}$ & $\%$ & - & 15.86 & 520 \\
\hline thresh3 & Take action: $\mathrm{SCC}=300,000$ cells $/ \mathrm{mL}$ & $\%$ & $+1-$ & 36.40 & 520 \\
\hline thresh4 & Take action: $\mathrm{SCC}=400,000$ cells $/ \mathrm{mL}$ & $\%$ & + & 33.17 & 520 \\
\hline thresh 5 & Take action: $\mathrm{SCC} \geq 500,000$ cells $/ \mathrm{mL}$ & $\%$ & + & 7.54 & 520 \\
\hline \multicolumn{6}{|c|}{ Information source } \\
\hline vet & 1 from veterinarian & $\%$ & - & 89.90 & 557 \\
\hline producer & 1 from another dairy producer & $\%$ & $+/-$ & 76.82 & 545 \\
\hline coop & 1 from milk cooperative representative & $\%$ & - & 49.37 & 543 \\
\hline extension & 1 from county agent/extension & $\%$ & - & 31.84 & 528 \\
\hline journals & 1 from farm journals & $\%$ & - & 58.56 & 551 \\
\hline drug & 1 from drug company & $\%$ & - & 58.56 & 551 \\
\hline \multicolumn{6}{|c|}{ State indicator } \\
\hline$k y$ & 1 if Kentucky & $\%$ & $+/-$ & 32.34 & 565 \\
\hline$s c$ & 1 if South Carolina & $\%$ & $+1-$ & 4.01 & 565 \\
\hline$v a$ & 1 if Virginia & $\%$ & - & 24.65 & 565 \\
\hline$g a$ & 1 if Georgia & $\%$ & $+/-$ & 9.42 & 565 \\
\hline ms & 1 if Mississippi & $\%$ & + & 3.37 & 565 \\
\hline$n c$ & 1 if North Carolina & $\%$ & - & 10.51 & 565 \\
\hline
\end{tabular}

${ }^{1}$ The frequency is reported for dichotomous data.

${ }^{2}$ Number of responses for specific variable.

${ }^{3} \mathrm{BTSCC}=$ bulk tank SCC.

${ }^{4}$ Scale: $1=$ strongly disagree to $5=$ strongly agree.

${ }^{5}$ Scale: 1 = not likely, $2=$ somewhat likely, 3 = very likely, 4 = almost certainly.

${ }^{6}$ PC-DART, Dairy Records Management System, Ames, Iowa, and Raleigh, North Carolina (http://www.drms.org/); DairyComp, Valley Agricultural Software, Tulare, California (http://web.vas.com/en/Support). 
Dairy processors or cooperatives may offer incentives to maintain low BTSCC (and therefore high-quality milk) or penalties for milk with high SCC. If dairy processors or cooperatives offer an incentive for a target BTSCC (incentive, 1 = yes), we expected current BTSCC would be relatively low. We hypothesized that farmers eligible for milk quality incentives (incentive) or who are subject penalties for high BTSCC (penalty, $1=$ yes) would report lower current BTSCC. Dairy operators receiving incentives for producing quality milk represented $89 \%$, whereas $76 \%$ of the respondents indicated they were penalized for producing poor-quality milk.

We were uncertain how the farm's business structure (soleprop and partner, both are binary) would affect current BTSCC. However, we hypothesized these entity definitions may be correlated with BTSCC because they proxy managerial practices. The percent of respondents classifying their operation as a sole proprietorship was $59 \%$, whereas $20 \%$ classified their operation as partnerships.

Operator Characteristics. Producers were asked if they believed mastitis could adversely affect their operation's financial position. We expected that farmers indicating concern over and worried about the financial consequences of mastitis on their operation (finance) would report lower BTSCC. The variable finance was measured with a question regarding how much respondents agreed or disagreed that the financial consequences of mastitis were troublesome (Likert scale; $1=$ strongly disagree to $5=$ strongly agree). On average, producers indicated they agreed that the financial consequences of mastitis were troublesome with an average response of 4.40 .

We hypothesized that current average BTSCC would be lower for respondents who expected to be operating the dairy in $5 \mathrm{yr}$ (continue). Maintaining a reputation for producing quality milk may also be perceived as an important component for the future solvency of the operation. Producers were asked how likely it was they would still be operating a dairy in 5 yr (Likert scale; $1=$ not likely at all to $4=$ almost certainly). Producers generally anticipated they would be operating their dairy in $5 \mathrm{yr}$, with an average across the respondents of 3.0. We expected lower BTSCC on dairies where producers anticipated operating over the next 5 yr.

Kumbhakar et al. (1991) found that dairy farm productivity was positively associated with education. We hypothesized that dairy farmers with a college education (educ, 1 = yes) would report lower BTSCC. The percent of producers who earned a college degree was $25 \%$. We constructed an experience index (exper) equal to the total number of years the operator made dairy managerial decisions divided by the individual's age (Lambert et al., 2014). We expected higher levels of exper would reflect accumulated knowledge about managing herd health and would be associated with lower BTSCC. The average experience index was 0.54.

A variable was included indicating that the manager and workers speak the same language (language, $1=$ yes). We were uncertain how this variable would correlate with current average BTSCC. A priori, one might hypothesize that when managers and employees speak the same language the risks of misunderstanding instructions and work orders would be minimized, which could contribute to maintaining parlor hygiene. However, speaking the same language does not necessarily imply that interlocutors mutually comprehend the concepts or ideas one intends to communicate. The percent of primary operators speaking the same language as their employees was $71 \%$.

Farm Management Practices. We hypothesized that individuals present in parlors during milking and actively engaged in milking (milking, 1 = yes) would report lower BTSCC. Individuals able to commit time to the hands-on management of their operation may be more attentive to parlor hygiene and, therefore, report lower average BTSCC. The percent of operators present during milking was $48 \%$.

We analyzed a set of Likert-scale questions pertaining to farmer perceptions of mastitis and its management (Table 3) to generate summary factors associated with perceived control over and concern about mastitis. Previous research determined farmer attitudes and behavior accounted for as much of $48 \%$ of the variation in BTSCC (Jansen et al., 2009). Factor scores were estimated using principal component analysis (PCA). An example of a question is, "Please indicate the extent to which you disagree or agree with each of these statements: Bad luck plays an important role in mastitis outbreaks." Response options ranged from $1=$ strongly disagree to $5=$ strongly agree. Given the Likert-scale nature of these questions, the factors were estimated using polychoric PCA (Kolenikov and Ángeles, 2004). Following Johnson and Wichern (2002), we considered statements with a rotated factor loading of an absolute value of 0.40 or greater as relevant to the factor. Cronbach's $\alpha$ indicates the reliability of the factors (i.e., how closely related the questions are as a group); an $\alpha$ between 0.5 and 0.6 is considered unreliable. An acceptable grouping was indicated when the parameter ranged between 0.6 and 0.7 ; strong groupings are indicated by $\alpha$ parameters above 0.7 (George and Mallery, 2003). Cronbach's $\alpha$ for factor 1 and factor 2, when considering statements with a rotated factor loading with an absolute value of 0.40 or greater, was 0.73 and 0.65 , respectively. 


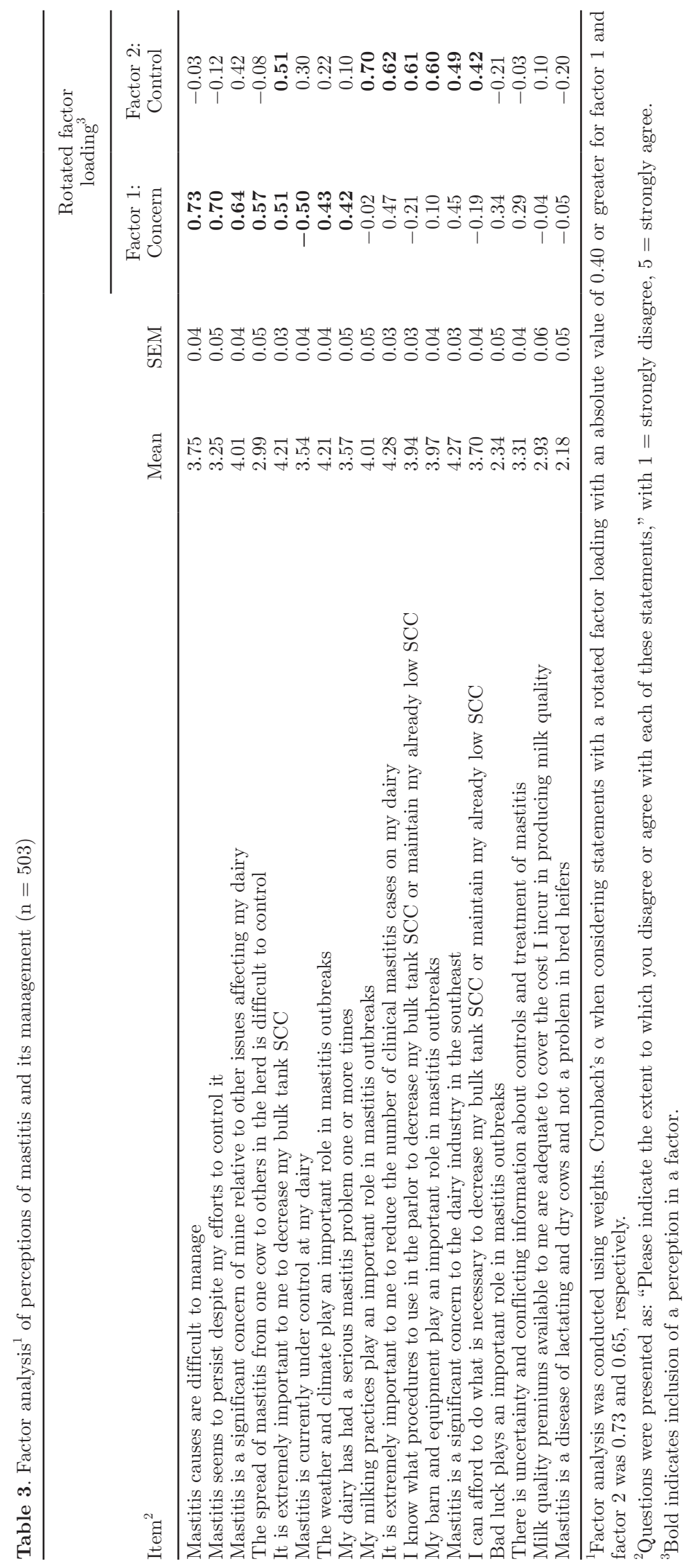


The PCA resulted in 2 dominant common factors (Table 3). Factor 1, concern, absorbed questions such as "Mastitis causes are difficult to manage" and "Mastitis seems to persist despite my efforts to control it." The average score for concern was 3.57. Factor 2, control, included questions such as "My milking practices play an important role in mastitis outbreaks." The average score for control was 5.14. We hypothesized that farmers who are more concerned (higher scores on the concern factor) about mastitis would have higher BTSCC. Conversely, we believed that farmers who believe they have more control over their mastitis prevention practices (higher scores on the control factor) would have lower BTSCC.

Computerized record keeping may provide early and more accurate detection of mastitis. Participation in dairy enhancement programs may also provide producers a network for detecting, preventing, and managing mastitis outbreaks. We hypothesized that if the respondent participated in a DHIA testing program (dhia, $1=$ yes), their current average BTSCC would be lower. The percent of operators participating in a DHIA was $40 \%$. Operators using electronic tracking systems to monitor mastitis (electronic, 1 = yes) may be able to detect and treat high BTSCC earlier, resulting in lower current BTSCC if steps are taken to manage cell counts. Electronic records systems were adopted by $20 \%$ of the respondents.

Action Thresholds. We hypothesized that producers who typically implement actions to manage BTSCC at relatively lower BTSCC readings would, on average, report lower average BTSCC. Producers were asked at what BTSCC they take action to manage mastitis. For example, when farmers implement measures to manage mastitis as indicated by the BTSCC reading of thresh 1 $=100,000$ (score of 1, 0 otherwise), we hypothesized the reported current average BTSCC would be lower. Alternatively, if the producer's BTSCC management action threshold was thresh4 $=400,000$ (score of 1,0 otherwise), then the reported current average BTSCC would be higher. There were 7 possible categories provided to respondents in intervals of 100,000 cells $/ \mathrm{mL}$. The top 3 categories, 500,000,600,000, and $>700,000$ cells $/ \mathrm{mL}$, were combined into the single category of $>500,000$ cells $/ \mathrm{mL}$. This category is a reference group for the regression analysis that follows. Most (36\%) operators stated a target BTSCC management threshold of 300,000 cells $/ \mathrm{mL}$, and $59 \%$ of the operators implemented action to address SCC when BTSCC was $\leq 300,000$ cells $/ \mathrm{mL}$.

Information Sources. We hypothesized that dairy farmers who obtain information about mastitis from veterinarians (vet), milk cooperative representatives $(c o-o p)$, county agents/extension representatives and online extension information (extension), farm journals (journals), and drug companies (drug) would report lower BTSCC (all binary variables). The number of producers using veterinarians and co-op representatives as information sources for mastitis was 90 and $49 \%$, respectively. Fifty-nine percent of the respondents consulted farm journals for information about mastitis. The number of producers consulting extension specialists was $32 \%$. The expected relationship between current average BTSCC and the use of other farmers (producer, $1=$ yes) as an information source on mastitis is uncertain. If producers are knowledgeable about mastitis and they share information with peers on how to manage it, then we would expect the relationship to be negative. If, on the other hand, the information conveyed by peers about mastitis were inaccurate, then the relationship would be positive. The percent of producers using farmer peers as information sources about mastitis was $77 \%$.

State Fixed Effects. State dummy variables are included to control for state-effects omitted in the survey, such as policies, costs and prices, and other unobserved factors. Examination of the state level summary statistics (Table 1) suggests that Virginia $(v a)$ and North Carolina $(n c)$ dairies would likely have a significantly lower monthly average BTSCC than other dairies across the combined region.

\section{Methods}

Least Squares Regression. We assumed a linearadditive relationship between current average BTSCC and the covariates. For operator $i$, monthly average BTSCC ( $b t s c c_{2014}$ ) was regressed on the lag of monthly average BTSCC $\left(\right.$ btscc $\left._{2013}\right)$, farm structure and operator characteristics, action threshold levels, farm management practices, information sources, and state dummy variables:

$$
\begin{array}{r}
\text { btscc }_{i, 2014}=\beta_{0}+\rho \cdot \text { btscc }_{i, 2013}+\text { FSC }_{i}+\text { OC }_{i}+\text { FSM }_{i} \\
+ \text { THRESH }_{i}+\text { INFO }_{i}+\text { STATE }_{i}+u_{i},
\end{array}
$$

with antecedents

(a) Farm structure: $F S C_{i}=\beta_{1} \cdot$ milkprod $_{i}+\beta_{2} \cdot$ cows $_{i}$ $+\beta_{3} \cdot$ penalty $_{i}+\beta_{4} \cdot$ incentive $_{i}+\beta_{5} \cdot$ oincome $_{i}+$ $\beta_{6} \cdot$ ofarm $_{i}+\beta_{7} \cdot$ soleprop $_{i}+\beta_{8} \cdot$ partner $_{i}$,

(b) Operator characteristics: $O C_{i}=\beta_{9}{\text {. } \text { language }_{i}+}$ $\beta_{10} \cdot$ continue $_{i}+\beta_{11} \cdot$ educ $_{i}+\beta_{12} \cdot$ exper $_{i}+\beta_{13}$. finance $_{i}$,

(c) Farm management practices: $F M P_{i}=\beta_{14}$. milking $_{i}+\beta_{15} \cdot$ concern $_{i}+\beta_{16} \cdot$ control $_{i}+\beta_{17}$. dhia $_{i}+\beta_{18}$ electronic, 
(d) Action threshold: THRESH $H_{i}=\beta_{19} \cdot$ thresh $_{i}+$ $\beta_{20} \cdot$ thresh $_{i}+\beta_{21} \cdot$ thresh $_{i}+\beta_{22} \cdot$ thresh $_{i}$,

(e) Information sources: INFO ${ }_{i}=\beta_{24} \cdot$ vet $_{i}+\beta_{25}$. producer $_{i}+\beta_{26} \cdot$ coop $_{i}+\beta_{27} \cdot$ extension $_{i}+\beta_{28}$. journal $_{i}+\beta_{29} \cdot$ drug $_{i}$, and

(f) State fixed effects: $S T A T E_{i}=\beta_{30} \cdot k y_{i}+\beta_{31} \cdot s c_{i}$ $+\beta_{32} \cdot v a_{i}+\beta_{33} \cdot g a_{i}+\beta_{34} \cdot m s_{i}+\beta_{35} \cdot n c_{i}$,

where $u_{i}$ is an independent and identically distributed (iid) error term with mean zero and constant variance, and $\beta_{0}$ to $\beta_{35}$ are coefficients corresponding with the independent variables. Tennessee is the reference group for the state fixed effects. The coefficient $\rho$ is the proportional contribution of the previous BTSCC count to the current count. As Wooldridge (2006) demonstrate, the lagged monthly BTSCC is correlated with the error term. Estimating the linear model with ordinary least squares would generate biased and inconsistent parameter estimates and standard errors. We used an instrumental variable regression procedure to attend to the endogeneity of the lagged SCC. The instrumental variables were the BTSCC reported by the operator in 2011 ( btscc $_{2011}$ ) and the dairy's goal for maintaining their herd at or below a level (as a percent of the herd) infected with clinical mastitis (goal). The goal variable was categorical, with 7 levels $(1=5 \%, 2=10 \%, 3=$ $15 \% \ldots 7=40 \%)$. The average BTSCC reading for 2011 was 319,786 cells $/ \mathrm{mL}$, and the average of the goal index was 1.37 .

We estimated equation 2 with a 2 -step general method of moments estimator (Hansen, 1982; Baum et al., 2010). The main effect estimates and standard errors of this estimator are robust to arbitrary forms of heteroscedasticity. Instrument validity was determined using several statistics. Underidentification was assessed using Kleibergen and Paap's (2006) Lagrange multiplier reduced rank statistic. The null hypothesis was that the instruments excluded from equation 2 were irrelevant. Rejection of the null hypothesis suggested the model was identified. The second key assumption was that the excluded instruments, goal and $b t s c c_{2011}$, were correlated with $b_{t s c c_{2013}}$. This assumption was tested using Kleibergen and Paap's (2006) rank F statistic. Rejection of the null hypothesis (weak instruments) suggested the excluded instruments were sufficiently correlated with $b_{s c c}{ }_{2013}$. The third key statistic was that goal and

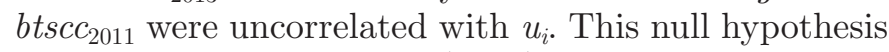
was tested using Hansen's (1982) $J$ statistic.

Collinearity Diagnostics. Variance inflation factors (VIF; Gujarati and Porter, 2009) and collinearity conditions indexes (Belsley et al., 1980) were calculated to evaluate the degree to which multicollinearity may affect the sign of the main effect estimates and inflation of the standard errors. We used a VIF cut-off of 10 and a collinearity conditions index of 30 to gauge the extent to which multicollinearity might be compromising the estimates.

Linear Contrasts and Comparisons. All $(0,1)$ variables were orthogonally restricted, such that the model intercept $\left(\beta_{0}\right)$ is the conditional mean of average current BTSCC across all states (Lentner and Bishop, 1993). For example, the dummy variable for state $s\left(d_{s}\right)$ is transformed as $r_{s}=d_{s}-d_{r e f}$, where $d_{r e f}$ is a reference state. For state $s$, the average BTSCC, holding other factors constant, was $\mu_{s}=\beta_{0}+\beta_{s}$. For the reference group, $\mu_{r e f}=\beta_{0}-\Sigma_{s} \beta_{s}$. For other indicator variables, the average effect of using extension as a source of information about mastitis on BTSCC, for example, was estimated as $\mu=\beta_{0}+\beta_{20}$. Standard errors of these linear combinations were estimated with the delta method.

\section{RESULTS}

Table 4 reports the regression results. The mean VIF was 2.49 , with a maximum value of 8.02 . The collinearity condition index was 32.46. Collinearity does not appear to be a problem with respect to coefficient signs and the size of the standard errors. The Kleibergen and Paap (2006) Lagrange multiplier statistic is significant at the $1 \%$ level (Lagrange multiplier $=37.98$ ), indicating that the excluded instruments (goal and btscc $_{2011}$ ) are relevant for explaining the lagged dependent variable, btscc $_{2013}$. The Kleibergen and Paap (2006) F-statistic ( $F$ $=20.57)$ exceeds the Stock and Yogo (2005) critical values at the $10 \%$ validity level $\left(F_{\text {crit }}=19.93\right)$. Therefore, we rejected the null hypothesis that the instruments were weak (i.e., uncorrelated with the lagged BTSCC variable; Baum et al., 2007). The null hypothesis that the instruments were orthogonal to the model residuals could not be rejected at any conventional level (Hansen's $J=0.09, P=0.77)$. These diagnostics suggest that the model was identified and the instruments were valid, supporting the use of the 2-step general method of moments estimator. The model explained $65 \%$ of the variation in current average BTSCC.

\section{Farm Structure Characteristics}

The lagged BTSCC $\left(\right.$ btscc $\left._{2013}\right)$ was a positive predictor of current year (2014) BTSCC. Holding other factors constant, average BTSCC in the year before the survey contributed to about $30 \%$ of the cell count per milliliter in $2014(P<0.10)$. Milk quality incentives and penalties were, ceteris paribus, uncorrelated with BTSCC during the survey year. Dairy size and 


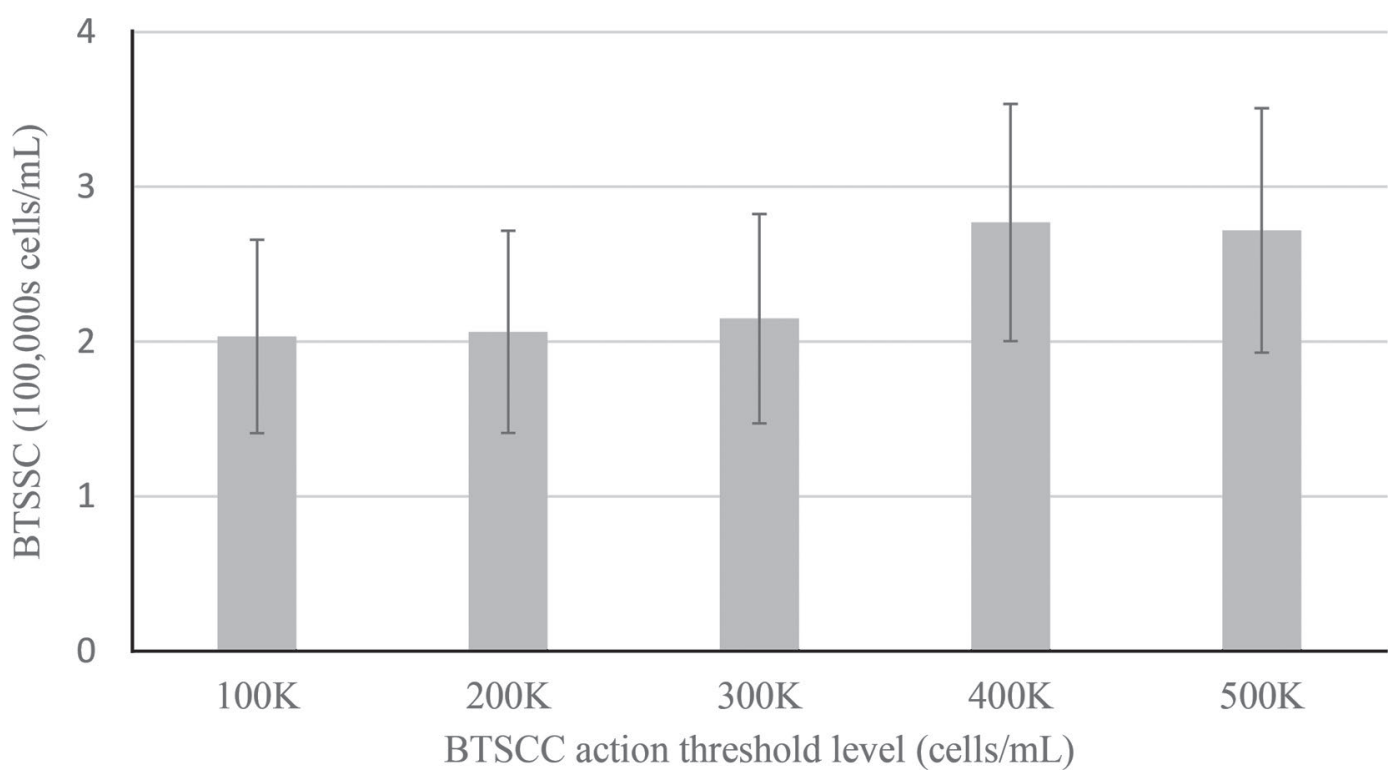

Figure 1. Bulk tank somatic cell counts (BTSCC; cells/mL) and action thresholds. Lines on bars are SE of the estimate. Note: K = 1,000.

spondents who expected to operate (or who expected a family member to operate) the dairy after 2019 reported, on average, lower BTSCC $(-12,933, P<0.01)$. Respondents who worried about the financial consequences of mastitis reported higher BTSCC $(10,548$ cells $/ \mathrm{mL}, P<0.10)$. This could be explained if farmers who had mastitis problems also had greater financial concerns regarding the consequences of mastitis. Current average BTSCC was uncorrelated with earning a college degree.

\section{Farm Management Practices}

All else equal, respondents who monitored the parlor during and participated in milking had a lower BTSCC $(-14,382, P<0.01)$. The factor scores that proxy general anxiety about (concern) and perceived control over (control) mastitis were significantly correlated with current average BTSCC. A 1 standard deviation increase in concern corresponded with a 17,706 cells $/ \mathrm{mL}$ increase in BTSCC $(P<0.10)$. A 1 standard deviation increase in perceived control over mastitis was associated with a 19,167 cells $/ \mathrm{mL}$ decrease in BTSCC $(P<$ 0.01). Participation in a DHIA and the use of electronic record-keeping systems were uncorrelated with current average BTSCC.

\section{Action Thresholds}

Producers taking action to reduce BTSCC at tank readings of $100,000,200,000$, or 300,000 reported lower average BTSCC (Table 4 and Figure 1). The BTSCC progressively decreased when producers took action to treat mastitis at lower BTSCC levels. The BTSCC of producers treating mastitis at the 300,000 and below threshold were not different $(P=0.79)$. We found greater variability in the BTSCC of producers treating for mastitis at levels above 300,000 cells $/ \mathrm{mL}$. The BTSCC reading of producers treating their herd for mastitis when tank readings were $\leq 300,000$ (mean \pm SE; $208,153 \pm 64,337$ ) was significantly lower than producers treating mastitis above this threshold $(274,389$ $\pm 76,887 ; P<0.01)$.

\section{Information Sources}

Dairy operators receiving information from veterinarians about the detection, management, and treatment of mastitis reported lower BTSCC concentrations $(-26,110$ cells $/ \mathrm{mL}, P<0.05)$. Operators who consulted extension also reported lower average BTSCC $(-9,047$ cells $/ \mathrm{mL}, P<0.10)$. The other sources of information pertaining to the management and treatment of mastitis included were uncorrelated with current average BTSCC.

\section{State-Average BTSCC}

The conditional average current BTSCC across all states was $271,832 \pm 78,972$ cells $/ \mathrm{mL}$ (estimate $\pm \mathrm{SE}$, Table 4). The current average BTSCC reported by producers in Virginia and North Carolina were significantly lower than the average across all dairy operators surveyed $[-23,323(P<0.05)$ and $-52,251$ cells $/ \mathrm{mL}$ 
$(P<0.01)$, respectively]. For example, Virginia had an average BTSCC of 248,509 (constant term $+v a$ coefficient) compared with the regional average of a BTSCC of 271,832. The state-average BTSCC reported by producers in other states were not different from the combined, regional average.

\section{DISCUSSION}

Several studies worldwide have examined how mastitis management practices affect BTSCC management (e.g., Yalcin et al., 1999; Norman et al., 2000; Rodrigues and Ruegg, 2005; Valeeva et al., 2007; Wenz et al., 2007; Jansen et al., 2009; Schewe et al., 2015). Our study contributes to this body of research by analyzing primary survey data of dairy farms in Georgia, Mississippi, Kentucky, North Carolina, South Carolina, Tennessee, and Virginia. The analysis determined how farm business and operator variables affect BTSCC in a southeastern US dairy herd. Recently in the United States, Schewe et al. (2015) analyzed a survey that examined producer attitudes and operational characteristics affecting BTSCC management in Michigan, Pennsylvania, and Florida diaries. We contributed to this existing body of literature by exploring factors affecting BTSCC in the southeastern United States, a region associated with a recent large-scale decline in dairy production (Herndon, 2011) and higher average BTSCC levels than the US average (Wenz et al., 2007; USDAAPHIS, 2013). Our findings support those reported by USDA-APHIS (2013) and Wenz et al. (2007), who also found southeastern dairies to have elevated BTSCC compared with other regions of the United States. We found that the average BTSCC among surveyed dairies was 254,479 cells/mL, which is much higher than those reported in Florida, Michigan, and Pennsylvania dairies $(186,000$ cells/mL; Schewe et al., 2015). Our finding also corroborates research by Herndon (2011), who postulated that the decline in milk production in the southeast is partially due to on-farm factors, such as slower rates of productivity gains in southeastern cows compared with national averages. Furthermore, we found that higher previous-year BTSCC levels were associated with higher levels of current-year BTSCC. This positive correlation suggests that producers with consecutive years of elevated BTSCC may not be fully adopting or implementing the numerous best practice control measures that could be used to reduce BTSCC. Olde Riekerink et al. (2005) found that, even though mastitis management practices are available to Canadian producers, operators did not always fully adopt these tools. Results from Olde Riekerink et al. (2005) provide a possible explanation as to why the producers surveyed in the southeastern states experienced elevat- ed BTSCC levels in consecutive years. For example, despite knowledge that BTSCC levels were high in a previous year, producers may not have fully adopted all available mastitis-control practices to lower BTSCC. Results of the current study also found that if the dairy had farm operations unrelated to their dairy, BTSCC levels were higher. It is possible that producers with operations in addition to their dairy may not be adopting all available mastitis-management tools because they may not consider their dairy operations as their primary income-generating activity and do not monitor its performance as closely.

Variables used to proxy the size of the surveyed dairy farm (i.e., dairy herd size and average milk production) were unimportant with respect to explaining BTSCC among dairies in southeastern states. Previous literature regarding the association between herd size and BTSCC is mixed. In Ireland and the United Kingdom, Archer et al. (2013) found that as herd size increased, BTSCC also increased. In Canada, Elmoslemany et al. (2010) found that bulk tank coliform count, which is also a measure of milk quality, was higher for larger herd sizes. Other US studies found that larger herds are associated with lower BTSCC (Norman et al., 2000; Jayarao et al., 2004; Wenz et al., 2007; Ingham et al., 2011); however, Schewe et al. (2015) did not establish any association between the number of cows on a dairy and BTSCC in Florida, Michigan, and Pennsylvanian dairies in their general population model. Among respondents with employees, Schewe et al. (2015) found that herds with greater than 600 cows tended to have higher BTSCC levels.

In our study, education and on-farm experience were unrelated to BTSCC. Schewe et al. (2015) found that among farms with nonfamily employees, respondents with more years of experience on the dairy farm were associated with higher farm BTSCC. In the current study, farms expected to be in operation in $5 \mathrm{yr}$ were associated with lower BTSCC. This is consistent with expectations given farms with better medium-term financial health are likely have lower BTSCC because mastitis reduction results in increased profits (Allore and Erb, 1998; Yalcin et al., 1999; Jones and Bailey, 2009; Cha et al., 2011).

Respondents who worried about the financial consequences of mastitis were associated with higher BTSCC, which is opposite what we hypothesized. Nonetheless, this finding is logical, as individuals who have problems with mastitis may be more worried about its financial consequences because mastitis causes increased costs (Ott, 1999; Jones and Bailey, 2009; Cha et al., 2011; Liang et al., 2017). Valeeva et al. (2007) also found that economic motivations are strongly associated with actions to manage mastitis. Dairy farm employees 
speaking the same language as the primary decision maker resulted in higher BTSCC. This result is perhaps counterintuitive, but Schewe et al. (2015) found in Michigan, Pennsylvania, and Florida that Englishspeaking respondents were associated with higher dairy BTSCC compared with non-English respondents.

In terms of farm management practices, respondents who monitored the parlor during milking and participated in milking had a lower BTSCC. This implies that a hands-on managerial approach could help curb the incidence of mastitis. Unexpectedly, participation in a DHIA and the use of electronic record-keeping systems were not related to BTSCC. The concern factor, which included survey questions such as "Mastitis causes are difficult to manage," was related to higher BTSCC. This is consistent with expectations considering farmers concerned about mastitis likely are faced with mastitis problems on their farms. Meanwhile, the control factor, which included survey questions such as "My milking practices play an important role in mastitis outbreaks," was related to lower BTSCC. This result was expected considering farmers who take responsibility of controlling for mastitis would be more likely to adopt available mastitis control practices (Hogeveen and Osteras, 2005) and be associated with lower BTSCC. The result that both factors of the attitudinal scales were significant in explaining BTSCC is consistent with previous surveys (Jansen et al., 2009; Schewe et al., 2015).

The BTSCC was progressively lower when producers took action to treat mastitis at lower BTSCC levels. This is consistent with Schewe et al. (2015), who found that farms had higher BTSCC if they only became concerned about mastitis when BTSCC was greater than 300,000 cells/mL. Farmers who obtained mastitis management information from veterinarians and extension personnel had lower BTSCC. This is consistent with the meta-analysis of Baumgart-Getz et al. (2012) of farm technology adoption literature, which found that access to and the quality of information was strongly associated with farmers' adoption of best management practices.

Finally, it was found that dairies located in North Carolina and Virginia had lower BTSCC than the other surveyed states. However, both of these states had BTSCC greater than the average BTSCC level that Schewe et al. (2015) reported for Florida, Michigan, and Pennsylvania dairies. Our study is the first known survey-based study to examine how farm characteristics and management practices are associated with BTSCC in the southeastern United States. Continued research regarding why southeastern US dairies have higher BTSCC levels than dairies in other US regions is important to gauge producers' level of proactive man- agement of BTSCC, as demand for higher-quality milk increases and dairy profit margins continue to narrow.

\section{CONCLUSIONS}

The goal of this research was to determine the farm business and operator variables associated with BTSCC in southeastern US dairy herds. We found that higher previous-year BTSCC levels, managing farm operations not related to the dairy, using a common language on the farm, considering the financial consequences of mastitis worrisome, and concern about the occurrence of mastitis were related to higher BTSCC on dairies. We found dairies that were sole proprietorships or partnerships as opposed to a corporation or other entity type, dairies that were likely to be operating in $5 \mathrm{yr}$, and dairies that had a primary decision maker actively in the barn at each milking had lower BTSCC. Additionally, operations exhibiting perceived control over mastitis, who took action against mastitis at a BTSCC less than 300,000 cells $/ \mathrm{mL}$, received information from veterinarians and extension personnel about mastitis, and were located in North Carolina or Virginia had lower BTSCC. These results provide information regarding the importance of farm structure characteristics, operator characteristics, farm management practices, and information sources on the management of BTSCC in southeastern US dairies. In general, results suggest that proactive producers (i.e., those that perceive they can control BTSCC and seek information from reliable sources) were more likely to have lower BTSCC. Further implementation of these proactive procedures may help improve milk quality, as evidenced by lowered BTSCC, across the southeastern United States.

\section{ACKNOWLEDGMENTS}

This material is based upon work that is supported by the National Institute of Food and Agriculture, USDA, Washington, DC, under award number 201368004-20424. Any opinions, findings, conclusions, or recommendations expressed in this publication are those of the author(s) and do not necessarily reflect the view of the USDA.

\section{REFERENCES}

Allore, H. G., and H. N. Erb. 1998. Partial budget of the discounted annual benefit of mastitis control strategies. J. Dairy Sci. 81:2280 2292.

Archer, S. C., F. McCoy, W. Wapenaar, and M. J. Green. 2013. Association of season and herd size with somatic cell count for cows in Irish, English, and Welsh dairy herds. Vet. J. 196:515-521. 
Baum, C. F., M. E. Schaffer, and S. Stillman. 2007. Enhanced routines for instrumental variables/GMM estimation and testing. Stata J. $7: 465-506$.

Baum, C. F., M. E. Schaffer, and S. Stillman. 2010. ivreg2: Stata module for extended instrumental variables/2SLS, GMM and AC/HAC, LIML and k-class regression. Accessed Aug. 10, 2016. https://ideas.repec.org/c/boc/bocode/s425401.html.

Baumgart-Getz, A., L. S. Prokopy, and K. Floress. 2012. Why farmers adopt best management practice in the United States: A metaanalysis of the adoption literature. J. Environ. Manage. 96:17-25. https://doi.org/10.1016/j.jenvman.2011.10.006.

Belsley, D., E. Kuh, and R. Welsch. 1980. Regression Diagnostics. Wiley, New York, NY.

Cha, E., J. A. Hertl, L. W. Tauer, G. Bennett, R. N. González, Y. H. Schukken, F. L. Welcome, and Y. T. Gröhn. 2011. The cost and management of different types of clinical mastitis in dairy cows estimated by dynamic programming. J. Dairy Sci. 94:4476-4487.

Elmoslemany, A. M., G. P. Keefe, I. R. Dohoo, J. J. Wichtel, H. Stryhn, and R. T. Dingwell. 2010. The association between bulk tank milk analysis for raw milk quality and on-farm management practices. Prev. Vet. Med. 95:32-40.

George, D., and P. Mallery. 2003. SPSS for Windows Step by Step: A Simple Guide and Reference. 4th ed. Allyn \& Bacon, Boston, MA

Gujarati, D. N., and D. Porter. 2009. Basic Econometrics. 5th ed. McGraw-Hill Irwin, Boston, MA.

Hansen, L. P. 1982. Large sample properties of generalized method of moments estimators. Econometrica 50:1029-1054.

Herndon, C. W. 2011. How the Southeast is different. Hoard's Dairyman. Accessed Aug. 20, 2016. http://hoards.com/article-2392 -hoard's-dairyman-article-how-the-southeast-is-different.html.

Hogeveen, H., and O. Osteras. 2005. Mastitis management in an economic framework. Pages 41-52 in Mastitis in Dairy Production: Current Knowledge and Future Solutions. Wageningen Academic Publishers, Wageningen, the Netherlands.

Ingham, S. C., Y. Hu, and C. Ané. 2011. Comparison of bulk-tank standard plate count and somatic cell count for Wisconsin dairy farms in three size categories. J. Dairy Sci. 94:4237-4241.

Jansen, J., B. H. P. Van den Borne, R. J. Renes, G. van Schaik, T. J. G. M. Lam, and C. Leeuwis. 2009. Explaining mastitis incidence in Dutch dairy farming: The influence of farmers' attitudes and behaviour. Prev. Vet. Med. 92:210-223. https://doi.org/10.1016/j .prevetmed.2009.08.015.

Jayarao, B. M., S. R. Pillai, A. A. Sawant, D. R. Wolfgang, and N. V Hegde. 2004. Guidelines for monitoring bulk tank milk somatic cell and bacterial counts. J. Dairy Sci. 87:3561-3573.

Johnson, R. A., and D. W. Wichern. 2002. Applied Multivariate Statistical Analysis. Prentice Hall, Upper Saddle River, NJ.

Jones, G. M., and T. L. Bailey. 2009. Understanding the basics of mastitis. Virginia Cooperative Extension. Publication 404-233. Virginia Tech, Blacksburg.

Kleibergen, F., and R. Paap. 2006. Generalized reduced rank tests using the singular value decomposition. J. Econom. 1331:97-126. https://doi.org/10.1016/j.jeconom.2005.02.011.

Kolenikov, S., and G. Ángeles. 2004. The use of discrete data in PCA: theory, simulations, and applications to socioeconomic indices. Carolina Population Center, University of North Carolina, Chapel Hill. Accessed Aug. 18, 2016. http://www.cpc.unc.edu/measure/ publications/wp-04-85.

Kumbhakar, S. C., S. Ghosh, and J. T. McGuckin. 1991. A generalized production frontier approach for estimating determinants of inefficiency in US dairy farms. J. Bus. Econ. Stat. 9:279-286.

Lambert, D. M., B. C. English, D. C. Harper, S. L. Larkin, J. A. Larson, D. F. Mooney, R. K. Roberts, M. Velandia, and J. M. Reeves. 2014. Adoption and frequency of precision soil testing in cotton production. J. Agric. Resour. Econ. 39:106-123.

Lentner, M., and T. Bishop. 1993. Experimental Design and Analysis. Valley Book Co., Blacksburg, VA.
Liang, D., M. Arnold, C. J. Stowe, R. J. Harmon, and J. M. Brewley. 2017. Estimating US dairy clinical disease costs with a stochastic simulation model. J. Dairy Sci. 100:1472-1486. https://doi.org/10 .3168/jds.2016-11565.

Lohr, S. L. 2010. Sampling: Design and Analysis. 2nd ed. Brooks/Cole Publishing Co., Pacific Grove, CA.

National Mastitis Council. 1999. Laboratory handbook on bovine mastitis. 2nd ed. National Mastitis Council, New Prague, MN.

Norman, H. D., R. H. Miller, J. R. Wright, and G. R. Wiggans. 2000. Herd and state means for somatic cell count from dairy herd improvement. J. Dairy Sci. 83:2782-2788.

Olde Riekerink, R. G. M., H. W. Barkema, D. T. Scholl, D. F. Kelton, and G. P. Keefe. 2005. Implementation of recommended mastitis prevention management practices and the herd level prevalence of contagious mastitis pathogens of Canadian dairy farms. Pages 587-592 in Mastitis in Dairy Production: Current Knowledge and Future Solutions. Wageningen Academic Publishers, Wageningen, the Netherlands.

Oliver, S. P., B. E. Gillespie, S. J. Headrick, H. Moorehead, P. Lunn, H. H. Dowlen, D. L. Johnson, K. C. Lamar, S. T. Chester, and W. M. Moseley. 2004. Efficacy of extended ceftiofur intramammary therapy for treatment of subclinical mastitis in lactating dairy cows. J. Dairy Sci. 87:2393-2400. https://doi.org/10.3168/ jds.S0022-0302(04)73361-5.

Ott, S. 1999. Costs of herd-level production losses associated with subclinical mastitis in US Dairy Cows. Pages 152-156 in Proc. 38th Annual Meeting of National Mastitis Council, Arlington, VA. National Mastitis Council, New Prague, MN.

Pighetti, G. M., and A. A. Elliott. 2011. Gene polymorphisms: The keys for marker assisted selection and unraveling core regulatory pathways for mastitis resistance. J. Mammary Gland Biol. Neoplasia 16:421-432.

Progressive Dairyman. 2014. 2014 national dairy statistics now available. Accessed Apr. 20, 2017. http://www.progressivedairy.com/ news/industry-news/2014-national-dairy-statistics-now-available.

Rodrigues, A. C. O., and P. L. Ruegg. 2005. Actions and outcomes of Wisconsin dairy farms completing milk quality teams. J. Dairy Sci. 88:2672-2680.

Schewe, R. L., J. Kayitsinga, G. A. Contreras, C. Odom, W. A. Coats, P. Durst, E. P. Hovingh II, R. O. Martinez, R. Mobley, S. Moore, and R. J. Erskine. 2015. Herd management and social variables associated with bulk tank somatic cell count in dairy herds in the eastern United States. J. Dairy Sci. 98:7650-7665. https://doi.org/ $10.3168 /$ jds.2014-8840.

Stock, J. H., and M. Yogo. 2005. Testing for weak instruments in linear IV regression. Pages 80-108 in D. W. K. Andrews and J. H. Stock, ed. Identification and Inference for Econometric Models: Essays in Honor of Thomas Rothenberg. Cambridge University Press, New York, NY.

USDA-APHIS. 2013. Determining U.S. Milk Quality Using Bulk-tank Somatic Cell Counts. 2012. APHIS Veterinary Services, Centers for Epidemiology and Animal Health, Information Sheet. \#684.0713. USDA APHIS, Riverdale, MD.

Valeeva, N. I., T. J. G. M. Lam, and H. Hogeveen. 2007. Motivation of dairy farmers to improve mastitis management. J. Dairy Sci 90:4466-4477. https://doi.org/10.3168/jds.2007-0095.

Wenz, J. R., S. M. Jensen, J. E. Lombard, B. A. Wagner, and R. P. Dinsmore. 2007. Herd management practices and their association with bulk tank somatic cell count on United States dairy operations. J. Dairy Sci. 90:3652-3659. https://doi.org/10.3168/ jds.2006-592.

Wooldridge, J. M. 2006. Introductory Econometrics: A Modern Approach. 3rd ed. Thomson South-Western. Mason, OH.

Yalcin, C., A. W. Stott, D. N. Logue, and J. Gunn. 1999. The economic impact of mastitis-control procedures used in Scottish dairy herds with high bulk-tank somatic-cell counts. Prev. Vet. Med. 41:135-149. 